POLICY CHOICES FOR THE 1990s 
Also by Bela Balassa

THE HUNGARIAN EXPERIENCE IN ECONOMIC PLANNING THE THEORY OF ECONOMIC INTEGRATION

TRADE PROSPECTS FOR DEVELOPING COUNTRIES

CHANGING PATTERNS IN FOREIGN TRADE AND PAYMENTS (contributing editor)

ECONOMIC DEVELOPMENT AND INTEGRATION

TRADE LIBERALIZATION AMONG INDUSTRIAL COUNTRIES:

Objectives and Alternatives

STUDIES IN TRADE LIBERALIZATION: Problems and Prospects for the Industrial Countries (contributing editor)

THE STRUCTURE OF PROTECTION IN DEVELOPING COUNTRIES

EUROPEAN ECONOMIC INTEGRATION (contributing editor)

ECONOMIC PROGRESS, PRIVATE VALUES, AND PUBLIC

POLICY: Essays in Honor of William Fellner (contributing editor, with Richard Nelson)

POLICY REFORM IN DEVELOPING COUNTRIES

INDUSTRIAL DEVELOPMENT STRATEGY IN THAILAND

THE NEWLY INDUSTRIALIZING COUNTRIES IN THE WORLD ECONOMY

THE BALANCE OF PAYMENTS EFFECTS OF EXTERNAL SHOCKS AND OF POLICY RESPONSES TO THESE SHOCKS IN NON-OPEC DEVELOPING COUNTRIES (with André Barsony and Anne Richards)

DEVELOPMENT STRATEGIES IN SEMI-INDUSTRIAL ECONOMIES

TURKEY: Industrialization and Trade Strategy

MOROCCO: Industrial Incentives and Export Promotion-

* CHANGE AND CHALLENGE IN THE WORLD ECONOMY

* ECONOMIC INCENTIVES (contributing editor with Herbert Giersch)

TOWARD RENEWED ECONOMIC GROWTH IN LATIN

AMERICA (with Gerardo M. Bueno, Pedro Pablo Kuczynski and Mario Henrique Simonsen)

ADJUSTING TO SUCCESS: BALANCE OF PAYMENTS POLICY IN THE EAST ASIAN NICS (with John Williamson)

CHANGING TRADE PATTERNS IN MANUFACTURED GOODS:

An Econometric Investigation (with Luc Bauwens)

JAPAN IN THE WORLD ECONOMY (with Marc Noland)

* ECONOMIC POLICIES IN THE PACIFIC AREA DEVELOPING COUNTRIES

* Also published by Palgrave Macmillan 


\section{Policy Choices for the 1990s}

\section{Bela Balassa}

Professor Emeritus, Political Economy

The Johns Hopkins University, Baltimore

Foreword by W. Max Corden

Professor of International Economics

The Johns Hopkins University, Baltimore

School of Advanced International Studies, Washington

With a Personal Tribute by Sir Alan Walters

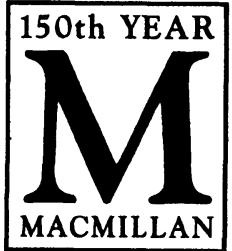




\section{(C) Carol Balassa 1993}

Foreword (C) W. Max Corden 1993

Bela Balassa: A Personal Tribute (C) Sir Alan Walters 1993

Softcover reprint of the hardcover 1st edition 1993 978-0-333-58227-5

All rights reserved. No reproduction, copy or transmission of this publication may be made without written permission.

No paragraph of this publication may be reproduced, copied or transmitted save with written permission or in accordance with the provisions of the Copyright, Designs and Patents Act 1988, or under the terms of any licence permitting limited copying issued by the Copyright Licensing Agency, 90 Tottenham Court Road, London W1P 9HE.

Any person who does any unauthorized act in relation to this publication may be liable to criminal prosecution and civil claims for damages.

First published 1993 by

THE MACMILLAN PRESS LTD

Houndmills, Basingstoke, Hampshire RG21 2XS

and London

Companies and representatives

throughout the world

ISBN 978-1-349-13035-1

ISBN 978-1-349-13033-7 (eBook)

DOI 10.1007/978-1-349-13033-7

A catalogue record for this book is available from the British Library. 


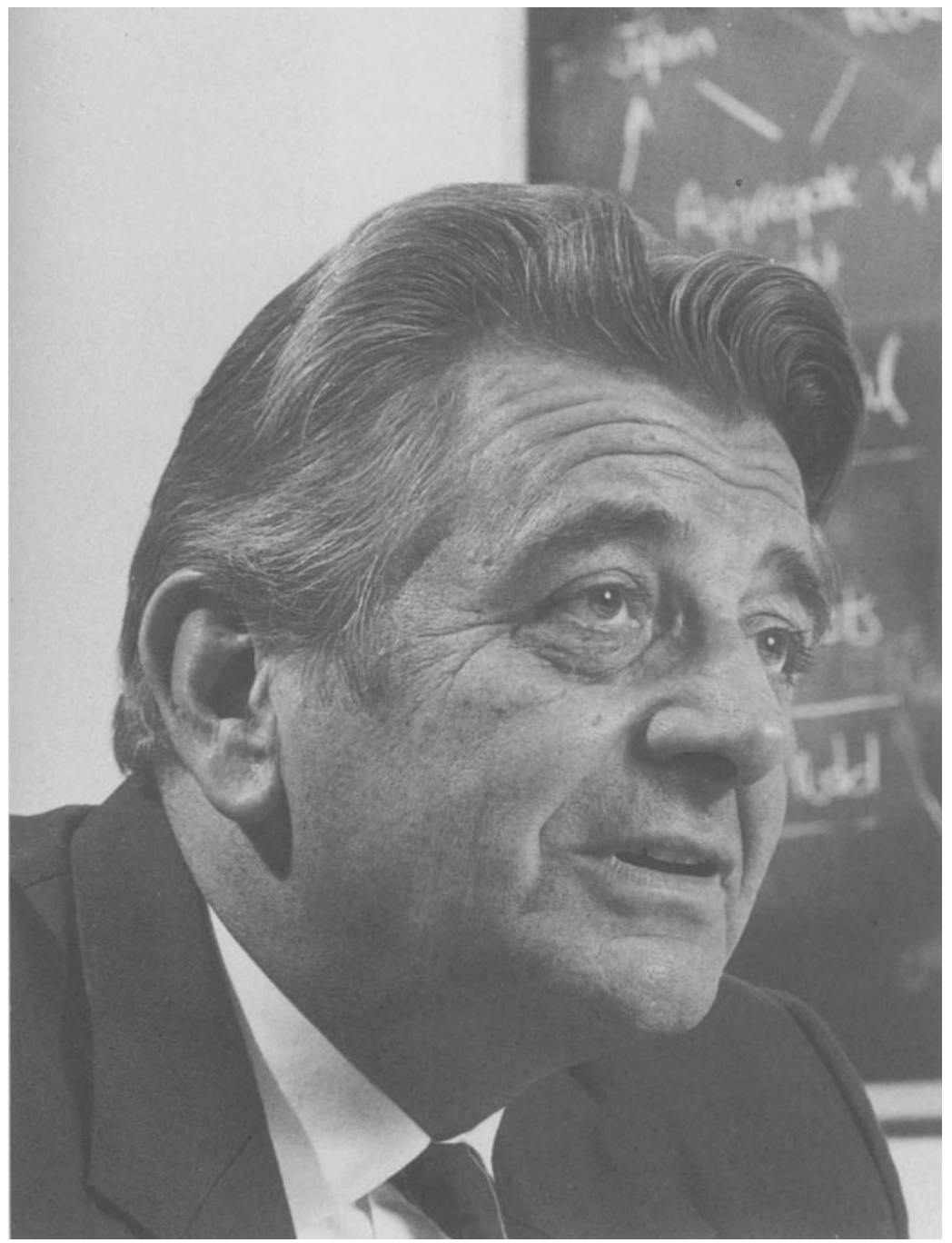

In memoriam

Bela Balassa

(1928-91) 


\section{Contents}

Bela Balassa Frontispiece v v

Acknowledgements ix

Foreword by W. Max Corden xii

Bela Balassa: A Personal Tribute by Sir Alan Walters xvi

PART I DEVELOPMENT STRATEGIES

1 Outward Orientation 3

2 Policy Choices in Newly-Industrializing Countries 56

PART II ADJUSTMENT POLICIES

3 A Conceptual Framework for Adjustment Policies 71

4 A Quantitative Appraisal of Adjustment Lending 92

PART III THE PUBLIC SECTOR IN DEVELOPING COUNTRIES

5 Public Enterprises in Developing Countries: Issues of $\begin{array}{ll}\text { Privatization } & 187\end{array}$

6 Public Finance and Economic Development 205

PART IV FINANCIAL LIBERALIZATION AND INTEREST RATES

7 Financial Liberalization in Developing Countries

8 The Effects of Interest Rates on Savings in Developing Countries

PART V PLANNING AND SOCIALIST REFORM

9 Indicative Planning in Developing Countries

10 Reflections on Perestroika and the Foreign Economic Ties of the USSR 
viii

11 Perestroika and its Implications for European Socialist Countries

12 Economic Integration in Eastern Europe

\section{PART VI THE GATT NEGOTIATIONS}

13 Subsidies and Countervailing Measures: Economic Considerations

14 Services in the United States

PART VII THE EEC ENLARGEMENT

15 Europe 1992 and its Possible Implications for Nonmember Countries

16 EMENA Manufactured Exports and EEC Trade Policy

PART VIII TRENDS IN ECONOMIC POLICIES

17 France before Europe 1992

18 Economic Policies of the Rocard Government

My Life Philosophy by Bela Balassa

Name and Author Index 


\section{Acknowledgements}

Soon after Bela's death, I found the table of contents and outline of the present volume among his papers, most of which had been written during Stanley Fischer's Vice-Presidency at the World Bank. From among the many devoted friends and colleagues who had generously offered support and encouragement throughout his illness, I turned to a small group to help carry out Bela's final plans.

Jaime de Melo, who, along with André Sapir, was responsible for the Festschrift volume that gave Bela so much pleasure, was a constant source of guidance and support in arranging the many details of publication. Professor Max Corden graciously found time in his own busy schedule to write the professional overview to the volume. Sir Alan Walters, who earlier had written a spontaneous tribute to Bela, allowed his statement to serve as a personal overview. Professors Carl Christ and Bruce Hamilton provided ongoing counsel, reflecting the devotion of Bela's colleagues and students at the Department of Political Economy of Johns Hopkins University. The unswerving friendship of the late Professor Jean Bénard of the University of Paris I (Panthéon-Sorbonne) will not be forgotten. Meta de Coquereaumont lent her editorial expertise, Rebecca Sugui provided logistic support, and Gabor Balassa carefully checked out final editorial questions.

Acknowledgements for this volume would be incomplete without special mention of Bela's outstanding medical team - Doctors John C. Price, Benjamin S. Carson, and Ding-Jen Lee of Johns Hopkins Hospital in Baltimore, and Dr Louis Balla in Washington. Their medical skills, combined with wise and compassionate counsel, permitted Bela to continue his beloved work until the final day of his life. That was his ultimate wish.

Washington, DC

CAROl BALASSA 
The following have kindly granted permission to reproduce copyright material appearing in this book:

Chad Evans Wyatt of Washington, DC, for the frontispiece photograph.

Elsevier Science Publishing Company, Inc., Amsterdam, The Netherlands, for Chapter 1 (H. Chenery and T.N. Srinivasan, editors, Handbook of Development Economics, volume II, 1989; pp. 16461689).

Westview Press, Boulder, Colorado, for Chapter 2 (P. Marer and A. Koves, editors, Foreign Economic Liberalization: Transformations in Socialist and Market Economies, 1991, pp. 71-80).

World Bank, Washington, DC

- for Chapter 3 (paper prepared as the background for Adjustment Lending: An Evaluation of Ten Years of Experience, Policy and Research Report no. 1, Country Economics Department, 1988)

- for Chapter 6 (Policy, Planning and Research Working Paper, no. 31, August 1988)

- for Chapter 9 (Policy, Research and External Affairs Working Paper, no. 439, May 1990)

- for Chapter 12 (Policy, Research and External Affairs Working Paper, no. 636, March 1991)

- for Chapter 14 (P.A. Messerlin and K.P. Sauvant, editors, Uruguay Round: Services in the World Economy, 1990).

Pakistan Development Review for Chapter 4 (Summer, 1989; 28; pp. 73-94).

Wayne University Press, Detroit, for Chapter 5 (M. Neumann and K.W. Roskamp, editors, Public Finance and Performance of Enterprises, 1989; pp. 417-33).

Transaction Publishers, New Jersey, for Chapter 7 (Studies in Comparative International Development, Winter 1990/91, 25, no. 4; pp. 56-70).

Banco Nazionale del Lavoro Quarterly Review, for Chapter 8 (March 1990; no. 172; pp. 101-18). 
Geonomics Institute for International Economic Advancement, Middlebury, for Chapter 10 (M. Kraus and R.D. Leibowtiz, editors, Perestroika and East-West Economic Relations: Prospects for the 1990s, New York University Press, New York, 1990; pp. 105-21).

Journal of World Trade for Chapter 13 (April, 1989, vol. 23, no. 3; pp. 63-79).

Institute for International Economics, Washington, DC, for Chapter 15 (J.J. Schott, editor, Free Trade Areas and US Trade Policy, 1989; pp. 293-312).

Economia for Chapter 16 (January 1990; pp. 89-122).

Tocqueville Review for Chapter 17 (1988/89; pp. 191-203).

Commentaire for Chapter 18 (Summer 1991, no. 54; pp. 307-14).

American Economist for "My Life Philosophy" (Summer 1989; pp. 16-23).

Note: The reprinted materials appear as in the original publications except that minor alterations have been made to the style and presentation for the purpose of publishing this collection of readings in book form. 


\section{Foreword}

Bela Balassa continued to have tremendous vitality to the end of his life. As he wrote himself in his life philosophy, he had the feeling of living on borrowed time during his last three years, 1988 to 1991, which is when he wrote the essays in this volume. Many of them have not been published before. They deal with some of the most important economic policy issues of that period and each one continues to be highly relevant. This is true even of Chapter 11 , which analyzes perestroika and was presented at a conference in Budapest in November 1989. It is worth reading with hindsight: 1989 was already rather late, but if Mr Gorbachev and his fluctuating team had understood its arguments and acted upon them, history might have been rather different. A common theme runs right through most of the papers, namely, the virtues of the free market and the costs of distortions. There is also a common method, a highlight of which is the comprehensive presentation of the empirical material relevant to each issue. Bela Balassa did not believe in making judgments purely on the basis of abstract arguments.

In this collection, in my view, two papers stand out. The first is the survey from the Handbook of Development Economics of "Outward Orientation" (Chapter 1). For many years of his life Bela Balassa has been an analyst of the consequences of inward and outward orientation of developing countries, and on the basis of his work, indeed, an advocate. Perhaps this has been the single most prominent theme in his writings for 20 years. This is an impressive survey which reviews all the issues and digests a massive literature. It should really be a basic reference for all students of developing countries. The other outstanding paper is "A Quantitative Appraisal of Adjustment Lending" (Chapter 4), written for the World Bank in 1988 as a basis for its systematic assessments of structural adjustment lending. ${ }^{1}$ This was a very influential paper; it shows how skillfully Bela Balassa could handle a difficult problem empirically.

To give a brief overview of the book, the first nine chapters all deal with policy issues for developing countries.

Chapter 1 is the Handbook chapter which gives strong support to the view that an outward orientation has yielded superior results for developing countries, leading to higher rates of growth than an 
inward-oriented development strategy. Among other things, this chapter reviews the complex issue of the relationship between export growth and the overall growth of economies. Chapter 2 follows up by comparing the policies applied and the effects of these policies in the Far Eastern and the Latin American newly-industrializing countries. The message that emerges is straightforward: outward-oriented policies have turned out to be superior. Chapter 3 is a brief and neat essay written for the World Bank that provides a conceptual framework for adjustment policies. Chapter 4 is the important paper on the quantitative appraisal of adjustment lending to which I have already referred.

Then follow four chapters that provide overviews of a number of important issues and give the reader valuable surveys of the relevant literature. Chapter 5 reviews the role of public enterprises in developing countries and issues of privatization. Chapter 6 deals with public finance: the effects of the budget deficit, the size of the public sector and public investment on economic development. Chapter 7 deals with financial liberalization, and Chapter 8 provides evidence on the effects of interest rates on savings. These four chapters together really make up a short introductory textbook on public finance and financial policy in developing countries.

Chapter 9 is a short, highly critical paper on indicative planning, something that was once very fashionable in developing countries and earlier in Europe - but that has turned out to be pretty pointless, and done harm by diverting attention and human resources from more important matters.

Chapter 10 was written in 1988 and deals with the foreign economic ties of the former Soviet Union. It makes various proposals for improving Soviet trade, stressing the crucial need for domestic policies to change in order for foreign trade to be optimized. By now these ideas are familiar, but Bela Balassa was one of the first to write systematically along these lines, and these few pages are still useful as setting out the issues clearly. Chapter 11 is the critical evaluation of perestroika written in 1989 to which I have already referred, and Chapter 12 inquires into the possible future relationships of the economies of the reforming socialist countries.

Next we come to several chapters on international trade issues. Chapters 13 and 14 deal with the GATT multilateral trade negotiations, Chapter 13 with the negotiations on subsidies and countervailing action, and Chapter 14 with the effects that liberalization of trade in services may have on the United States. The European 
Community enlargement progresses parallel with the GATT negotiations, and Chapter 15 considers its effects on nonmember countries and Chapter 16 its effects on the North African-Southern European region.

The final chapters deal with France. Chapter 17 considers the implications for France of the "1992" completion of the internal market. Chapter 18 reviews the economic policies of the Rocard Government. In Bela Balassa's judgment the record has been pretty good, though there is a particular need to reduce the budget deficit and generally raise national savings.

As a final reflection, certain features stand out in Bela Balassa's writings and his style.

The theory is implicit. He does not start off papers by laying out models, mathematical equations, and so on, and then proceed to empirical testing or policy discussion. This is a common approach these days, but gets rather boring to read when the models are obvious, at least to reasonably educated economists. His method presents no difficulties in these papers because the implicit models are quite orthodox and thus well-known. Most of the papers can be easily read by non-economists, though they will not usually be made aware of all the implicit assumptions.

The style is straightforward and unfussy, indeed low-key. The main facts and arguments are there, nothing is obscure, and there is no varnish. These papers are written for busy people. They want relevant facts, the main results from the literature, especially econometric evidence, and the main issues and arguments neatly laid out. Having read, or felt obliged to read, much that is varnished, fussy, pretentious, and sometimes obscure, this is all a relief. Of course, there is often a need for explicit theorizing when dealing with policyrelevant issues, particularly when the theory is new or in doubt. In certain papers, particularly the Handbook chapter (Chapter 1), I would have preferred to see some of it. But the Balassa style - so easy to read and yet hard to emulate - filled a great need, and one hopes that young economists, tempted by modern fashions, will recognize that this is the style that is often appropriate. For policy-oriented economists the world over, and especially for those concerned with developing countries, not least the staff of the World Bank, the sad passing away of this remarkable man is a great loss.

W. MAX CORDEN 
Note

1. See Country Economics Department, the World Bank, Adjustment Lending: An Evaluation of Ten Years of Experience, Washington, DC, 1989; and Country Economics Department, the World Bank, Adjustment Lending Policies for Sustainable Growth, Washington, DC, 1990.

Bela Balassa's own paper was written in advance of the first of these two papers, soon after the decision to make an appraisal was made. 


\section{Bela Balassa: A Personal Tribute}

In the 25 years or so that I have known Bela he continued to astonish me - right to the courageous end. There will never be another like him. God broke that mould 63 years ago.

I first heard of Bela in the mid-1960s when he produced his great paper on bias in national income comparisons. In 1966 we were both consultants at the World Bank, I a rather casual one but Bela was a resident economist. I was trying to sell my theories of pricing policies, while Bela had begun that long conversion of the Bank towards the great classical precepts of free trade and outward-oriented policies.

Bela reviewed my manuscripts on pricing policy with shrewdness and generosity. But through all his comments and conversations there was an abiding theme - Bela was a liberal in the grand European tradition from Adam Smith to Fritz Hayek. His teacher at Yale was the incomparable William Fellner, surely the most cultivated and subtle liberal economist of the postwar era.

But Bela's appreciation of a free and open society was no mere academic exercise. He had not only witnessed but had resisted the Russian invasion of Hungary in 1956 and, as one of the freedom fighters, he had fled for his life as well as his liberty. He knew firsthand the miseries of socialism and communism.

Through the 1960s and early 1970s, when the vicious cycle (of poverty), central planning, the promotion of state-owned heavy industry, and trade restrictions through high tariffs and low quotas were such fashionable concepts, Bela was never diverted from his vision of an open liberal society. Trade and commerce and all contacts with other nations were the only way in which Western civilization and material advance were spread to benefit all. Coming from a small country like Hungary, Bela was more subtly attuned to the liberating forces of international trade, commercial and cultural contacts.

Professionally Bela eschewed the massive complex modelling of economics that was then so fashionable and that then addled many an able brain. He forged his chain of argument in short sharp links. And while all the large complex models were suffocated by their pseudo 
sophistication, Bela's propositions on trade and development stand more firmly today than they ever did.

Whatever task Bela undertook, he discharged it with a determination and thoroughness that I could only admire - even envy. He was the terror of lazy-minded administrators. I recall when, elected to the Academic Council of Hopkins, he became convinced that tuition at Hopkins was far too low relative to alternative schools. For its own reasons the administration was opposed to a tuition hike. Bela advanced his case with a massive statistical analysis and a thoroughly argued and documented brief. Of course, he won the argument.

Nor was it only his work that brought forth this astonishing energy and organization. Bela and I shared a love for opera which we used to discuss on the frequent occasions that he accompanied me on the journey from Hopkins to Washington. Both of us collected opera videos with equal enthusiasm. But compared with my haphazard inventory Bela's collection was well-recorded and superbly organized. For the most part I, with only the tiniest twinge of conscience for being a free rider, was content to accept Bela's enthusiastic offer to lend me any items I wanted.

But Bela's generosity to me extended far beyond opera. He had the model life, I thought, for a policy economist - one foot in academe and one foot on the quarter-deck of the Bank. He encouraged me to join him at Hopkins and the Bank. Eventually in $1976 \mathrm{I}$ did. That was an important turning-point in my life for various reasons. But Bela had an even bigger influence on me later. In early 1980 I was dithering over an invitation to return to London, from my agreeable Hopkins/Bank position, to become the economic adviser to Mrs Thatcher. I had all sorts of reservations which I aired to Bela. But with that magnificent finality of judgment Bela said: "Of course you must take it. It is your great opportunity." He was right. I realized this when I could collect my thoughts. All the niggling doubts and uncertainties were trivial compared with the opportunities. Bela's view had a profound effect on my decision. I told him later indeed much later in 1989 - of the importance I placed on his advice. I believe he was pleased - truly he had every reason to be. He said that he knew I would go to London, but he had doubted whether I would return to Hopkins/Washington. Again, although I did return, Bela was nearer to the truth in his prediction.

Stories of Bela's fabulous ability to do three things at the same time abound. In a seminar he would simultaneously listen to the speaker and write a paper - and even, on occasion, engage in an intermittent 
sotto voce conversation (often with me). The really extraordinary thing was that he did all very well. His seminar comments and papers were all pithy and to the point. No one has really explained to me how Bela managed to do so many things so well at the same time. I think it was part of his genius which we, who lack such astonishing abilities, can only admire and never seek to emulate. The 27 books and 270 articles speak volumes! But Bela detested any waste of his time. He regarded his time as a precious wasting asset. How right he was! We had all hoped he would be with us for two or three more decades.

The loss is all the more poignant because, just as cancer struck, his beloved Hungary and all central Europe shook off the yoke of totalitarianism. Who better prepared and worthy to advise on this grand transition than Bela Balassa? He had the knowledge, the intellectual agility and the surety of fundamentals which can be gained only from long reflection and scholarship. Bela knew what would work and what would not - and indeed what was right and what was wrong. Although he made signal contributions (to the Hungarian Blue Ribbon Commission for example), the damned malignancy took its toll. His return to Budapest to receive all honours was a rare celebration of his incomparable will. Through all the pain and suffering he saw his ideas triumph. That is a lot.

Finally, in this immensely productive life as a professional economist par excellence, Bela also cherished a close and affectionate family. He always had time for Mara, Gabor and for Carol. When we talked about his children, a soft tenderness suffused those large brown eyes. He understood. 